\title{
A proposal for a new universal development commitment
}

Jonathan Glennie, Nilima Gulrajani, Andy Sumner, and Myles Wickstead*

December 2019 
Abstract: Most Organization for Economic Co-operation and Development countries have accepted, in principle at least, the 50-year-old commitment of contributing 0.7 per cent of gross national income to supporting the development of countries in the Global South. But what if all countries made a universal development commitment, meaning a scaled contribution? We propose a new universal and scaled financial commitment to development, informed by but not necessarily identical to official development assistance. This paper: (i) sets out how a new era is emerging of fewer very poor countries and higher global ambitions-for example, to end poverty; (ii) proposes a new way to raise and govern international public funds; (iii) discusses the possible size and use of contributions, and the evolution in global governance and democracy that a new deal would entail. We conclude with a set of questions that the proposal raises.

Key words: global inequality, poverty, growth, aid, official development assistance

JEL classification: I30, F35

Acknowledgements: Many thanks for research assistance to Kathleen Craig and Eduardo OrtizJuarez. We would like to thank the following for comments on earlier drafts: Owen Barder, Gerardo Bracho, Harpinder Collacott, John MacArthur, Simon Maxwell, and Kirsty O’Donnell, and those who participated in a round-table in May 2019.

* All authors: King's College London, United Kingdom; corresponding author: Andy Sumner, andrew.sumner@kcl.ac.uk.

This study has been prepared within the UNU-WIDER Academic Excellence project.

Copyright (C) UNU-WIDER 2019

Information and requests: publications@wider.unu.edu

ISSN 1798-7237 ISBN 978-92-9256-755-2

https://doi.org/10.35188/UNU-WIDER/2019/755-2

Typescript prepared by Luke Finley.

The United Nations University World Institute for Development Economics Research provides economic analysis and policy advice with the aim of promoting sustainable and equitable development. The Institute began operations in 1985 in Helsinki, Finland, as the first research and training centre of the United Nations University. Today it is a unique blend of think tank, research institute, and UN agency — providing a range of services from policy advice to governments as well as freely available original research.

The Institute is funded through income from an endowment fund with additional contributions to its work programme from Finland, Sweden, and the United Kingdom as well as earmarked contributions for specific projects from a variety of donors.

Katajanokanlaituri 6 B, 00160 Helsinki, Finland

The views expressed in this paper are those of the author(s), and do not necessarily reflect the views of the Institute or the United Nations University, nor the programme/project donors. 
This paper presents a proposal for a new universal and scaled financial commitment to development to accompany the UN Sustainable Development Goals (SDGs). Many have written about the need to end the 'aid' and 'charity' framing in development policy and discussions, as well as the need for governance to evolve away from the Organization for Economic Co-operation and Development (OECD), where official development assistance (ODA) governance currently sits, to the UN, where the SDGs were agreed. A proposal in the run-up to the SDG agreement put forward the idea that upper-middle-income countries (UMICs) could contribute 0.1 per cent of gross national income (GNI) to development finance so as to broaden the pool of contributors (see Schmidt-Traub and Sachs 2015). In a similar vein, Leigh and Glennie (2013) proposed a still larger set of contributors, noting that even the poorest countries already pay into some global funds, including the Global Fund to Fight AIDS, TB and Malaria. Further, many middle-income countries (MICs) are already providers of development co-operation (while usually, to some extent, simultaneously being recipients_-see Alonso et al. 2014).

This paper does the following: (i) it outlines a new era of fewer very poor countries and higher global ambitions (e.g. to end poverty), and subsequently argues that traditional understandings of aid are less relevant in today's context; (ii) it proposes a new general direction of travel for development finance; and (iii) it discusses what the money would be used for and what 'new bargain' would be needed in terms of a new global governance structure in order to garner support for this proposal. The paper is structured thus: Section 2 provides a brief history and outlines the new 'post-ODA' era for development finance; Section 3 outlines a general direction for a new universal commitment to development finance and discusses the specific, potentially contentious issues; Section 4 concludes with a discussion of the political challenges.

\section{Development trends: Looking back and looking forward}

\subsection{Historical trends in official development assistance}

A history of development finance must inevitably include a focus on the 0.7 per cent commitment (for more detail on the history, see Clemens and Moss 2005; Wickstead 2015: 128-31). The 0.7 per cent commitment was developed by the Pearson Commission in 1969. It was agreed by a UN General Assembly resolution on 24 October 1970 and was to be reached by the middle of the decade, starting off the second United Nations Development Decade. ${ }^{1}$ Sweden was the first country to meet the 0.7 per cent target, in 1974, followed shortly by the Netherlands, Norway, and Denmark. However, most OECD countries have failed to meet the 0.7 per cent target in any year since it was introduced. At present, the 0.7 per cent of GNI target is met only by the UK, Germany, Denmark, Norway, Luxembourg, and Sweden, as well as by three non-OECD countries, namely Qatar, Turkey, and Saudi Arabia. The US accepted the legitimacy of the target at the Monterrey Conference in Mexico in 2002, which President Bush attended, endorsing the need 'to make concrete efforts towards the target of 0.7\%'. In reality, the OECD (2018: 267) estimated net ODA

\footnotetext{
${ }^{1}$ In 1969, the Development Assistance Committee (DAC) of the OECD—then a forum for the most advanced economies but now including a number of emerging economies, as participants rather than formal members-adopted the concept of 'official development assistance', defined as those transactions designed to promote the economic and social development of developing countries, and which were concessional in character. In the same year, the DAC Chair published for the first time figures showing ODA as a percentage of GNI.
} 
in 2017 at a volume of US $\$ 146.6$ billion (and an average ODA/GNI ratio of 0.31 per cent) from $\mathrm{DAC}$ members and $\$ 15.2$ billion from non-DAC donors (see also the estimates of Luijkx and Benn 2017). ${ }^{2}$

The world in which the richer countries agreed to the 0.7 per cent commitment was perceived, with justification, in binary terms: the North was wealthy and the South was poor. Yet raising money itself has never been the only answer to the challenge of development. The capacity to mobilize domestic resources and formulate pro-poor social and economic policies remains paramount. Having declined somewhat in the 1990s, ODA gained prominence again over the 2000s. There was a great deal of energy visible in the 'Make Poverty History' campaign, and the UN Millennium Campaign, and the G8 members made a commitment to double aid to Africa. The HIV/AIDS crisis, the outcome-focused finance for global health, and the Heavily Indebted Poor Country (HIPC) debt relief initiative were also catalysts in generating broad political backing for the rise of ODA in the 2000s. The $2004 \mathrm{UK}$ timetable commitment to achieve 0.7 per cent and the spring 2005 commitment by the EC-15 to reach 0.7 per cent by 2015 , made possible by Germany's public pledge in particular, were also important in raising ODA volume.

Most view southern development co-operation as a complement to, rather than a substitute for, the North's commitment to the 0.7 per cent target. However, there is potentially scope for southern co-operation providers to take responsibilities for development co-operation, if those responsibilities are tailored to their own history and economic circumstances and, most importantly, differentiated in relation to those assumed by traditional donors in the North (Bracho 2015). Importantly, this investment could be closely linked to domestic development challenges, especially in cases where domestic resources are constrained and where high levels of visible domestic poverty continue to challenge public support for overseas giving. In a sense, the size of the commitment would be of secondary importance to its universality - that is, the capacity for a new common and collective approach to extend the principles of solidarity across the traditional binary of North/rich and South/poor.

\subsection{Global growth trends and the new 'middle'}

The 2000s were a period of rapid growth for many developing countries, not just China and India, including a number of countries in Africa. This led to a declining number of very poor countries, or countries officially classified as 'low-income countries' (see Figure 1). The financial crash of $2007 / 08$ threw this shift into even sharper focus, for as economic growth in many countries in the South continued, many economies in the North at best grew very slowly - a trend that continues to this day. Thus a new 'middle' - of middle-income countries- has become home to most of the population of the developing world. A second new 'middle' is that of the developing world's population living above the US $\$ 1.90$ poverty line, though not too far above and thus potentially vulnerable to falling back into poverty.

\footnotetext{
${ }^{2}$ Although more recent ODA volume data are available, we use these estimates as the DAC and non-DAC estimates are comparable.
} 
Figure 1: Number of low-income countries (LICs) and high-income countries (HICs), 1987-2030

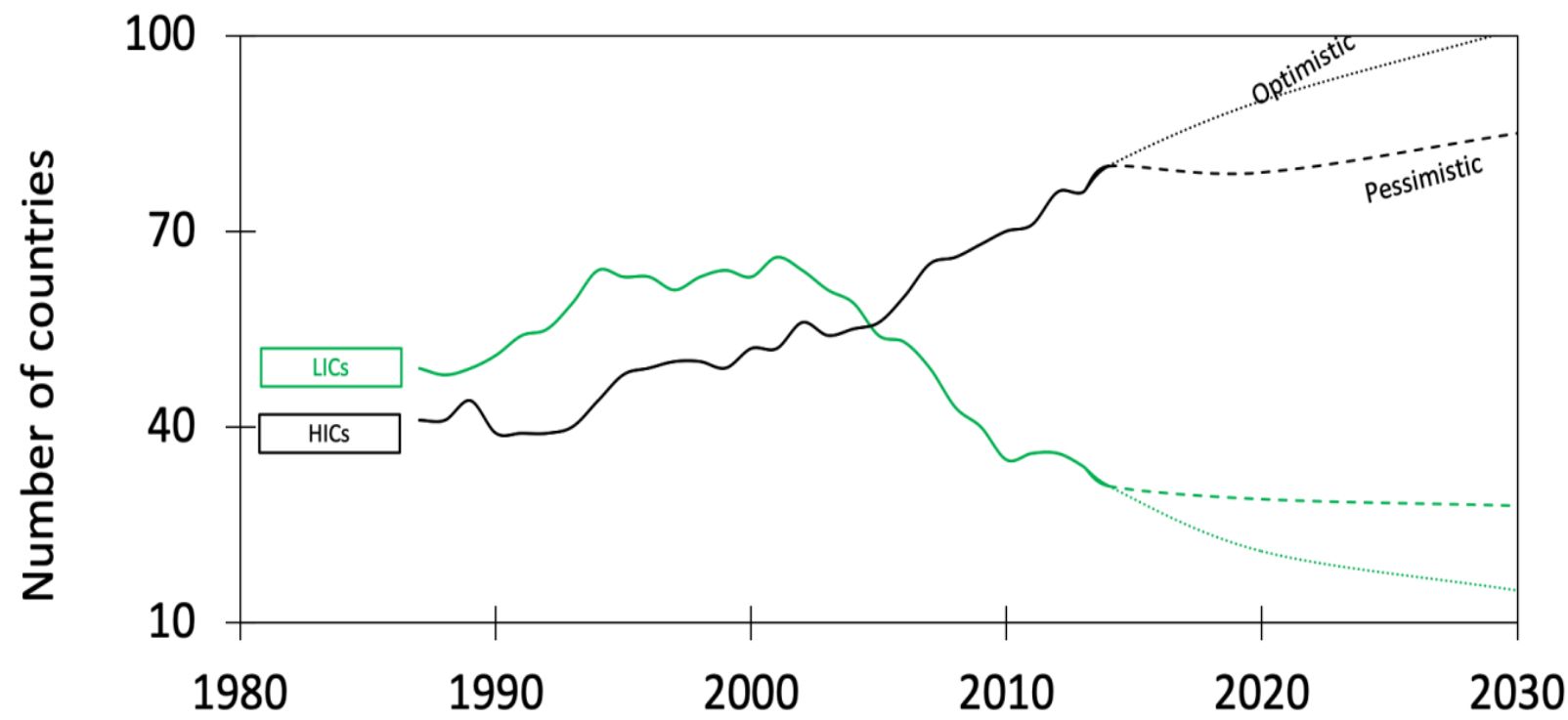

Source: authors' construction based on World Bank (2019b), and authors' projections using International Monetary Fund (IMF 2019) World Economic Outlook (WEO) growth projections (optimistic scenario) and half IMF WEO growth projections (pessimistic scenario).

Although there have been dramatic rises in mean gross domestic product (GDP) per person (and mean consumption per person) in most developing countries, a small set of about 25 countries remain 'stuck' in terms of development and are home to approximately 10 per cent of the population of the Global South. Most, but not all, of the 'stuck' countries are very-low-income countries. In contrast, the majority of people in the developing world now live in countries that are developing at a quicker pace. Hence, the current global economic climate, in which countries are developing at vastly different paces, has given rise to a binary in the Global South between a group of countries that are likely to remain low-income for some time to come, and a larger set of countries that have been growing much more substantially (see Figure 1). Moreover, although there has been impressive growth in much of the Global South, the gap between North and South remains huge. Even China still has a long way to go in terms of catching up with the richer countries of the world, in that China's GDP per capita (2011 purchasing power parity/PPP) stands at US $\$ 15,000$, which is still only around a quarter of the GDP per capita of the US. The most sophisticated long-run projections forecast that China will take three or more decades to catch up with the US (see Fouré et al. 2012).

\subsection{Trends in official development assistance/gross national income growth trends}

A related new binary has emerged as a result of the multi-speed developing world-varied levels of economic growth occurring within the Global South-which is of direct consequence to the future of development co-operation. That new binary is between (heavily) aid-dependent countries and developing countries where traditional ODA is low as a proportion of GNI. The first group is a set of about 30 countries which remain highly dependent on ODA, meaning that they receive over 5 per cent of GNI in ODA (see Table 1). These countries are home to approximately 600 million people, or 10 per cent of the population of the Global South. ${ }^{3}$ In contrast, in most developing countries ODA is, or soon will be, relatively small vis-à-vis domestic resources and

\footnotetext{
${ }^{3}$ Early signs of this new binary were identified in Maxwell (2006).
} 
non-public international flows. Approximately 90 per cent of the population of the Global South lives in these countries.

Table 1: Characteristics of developing countries by growth history (1990-2016) and ODA/GNI (2016)

\begin{tabular}{lrr}
\hline & $\begin{array}{r}\text { Number of } \\
\text { developing } \\
\text { countries }\end{array}$ & $\begin{array}{r}\text { Percentage of } \\
\text { developing-world } \\
\text { population (2016) }\end{array}$ \\
GDP per capita, PPP (constant 2011 international \$), average annual & & \\
growth, 1990-2016 & 25 & 10.1 \\
$<1 \%$ per capita/year & 22 & 12.2 \\
1-2\% per capita/year & 59 & 76.6 \\
$>2 \%$ per capita/year & 5 & 1.1 \\
No data & & 86.4 \\
Net ODA received as \% of GNI, 2016 & 72 & 6.4 \\
$<5 \%$ & 17 & 3.0 \\
$5-10 \%$ & 14 & 4.1 \\
$>10 \%$ & 8 & \\
No data & & \\
\hline
\end{tabular}

Notes: includes 111 developing countries with populations of more than 1 million people; no GDP per capita, PPP (constant 2011 international \$), available for Cuba, DPR Korea, Somalia, Eswatini, or Syria; no data on net ODA received as \% of GNI available for Bulgaria, Cuba, DPR Korea, Romania, Russia, Syria, Eswatini, or Venezuela.

Source: World Bank (2019b).

\subsection{Global poverty trends and a second new 'middle'}

Global poverty at the new extreme poverty line of US $\$ 1.90$ per day has declined, but the fall in the global poverty headcount when China is excluded is much more modest. This is not to say that the income growth among many of the poorest people in the world has not been positive. It is more to note the sobering fact that every 10 cents on the poverty line adds another 100 million people to the global poverty headcount (Edward and Sumner 2015).

In short, even though 'extreme' poverty under the World Bank's $\$ 1.90$ line has fallen from over 50 per cent of the population of developing countries to only about 10 per cent (see Figure 2), poverty remains at startling levels when taken at the World Bank's higher poverty lines of $\$ 3.20$ and $\$ 5.50$. Additionally, poverty measured as multidimensional poverty-including education, health, and nutrition poverty-is double that of the $\$ 1.90$ income poverty count, and multidimensional poverty is not only a problem for the poorest countries, the LICs (Robles Aguilar and Sumner 2020).

If a poverty line is used that is associated with a permanent escape from poverty $-\$ 13$ per day in 2011 PPP terms - some 80 per cent of the population of the Global South remains poor (see Figure 2). Further, poverty is widespread, not just in Sub-Saharan Africa and fragile or conflictaffected states. In short, there is a second new 'middle', which is the 70 per cent of the population of developing countries which lives above the $\$ 1.90$ poverty line but below the $\$ 13$ vulnerable-topoverty line.

In sum, the 0.7 target for ODA was developed 50 years ago in world where most developing countries were very poor countries and absolute poverty levels were very high. The contemporary developing world is one where a small group of countries remain very poor and highly aiddependent. In contrast, 90 per cent of the developing world's population lives in countries where traditional aid is at low levels. Although poverty at $\$ 1.90$ has fallen, much of the population of the developing world lives not too far above this threshold, with multidimensional poverty still affecting approximately 1.5 billion people. 
Figure 2: Global monetary poverty in developing countries, by various poverty lines, 1981 to present (\% of developing-world population)

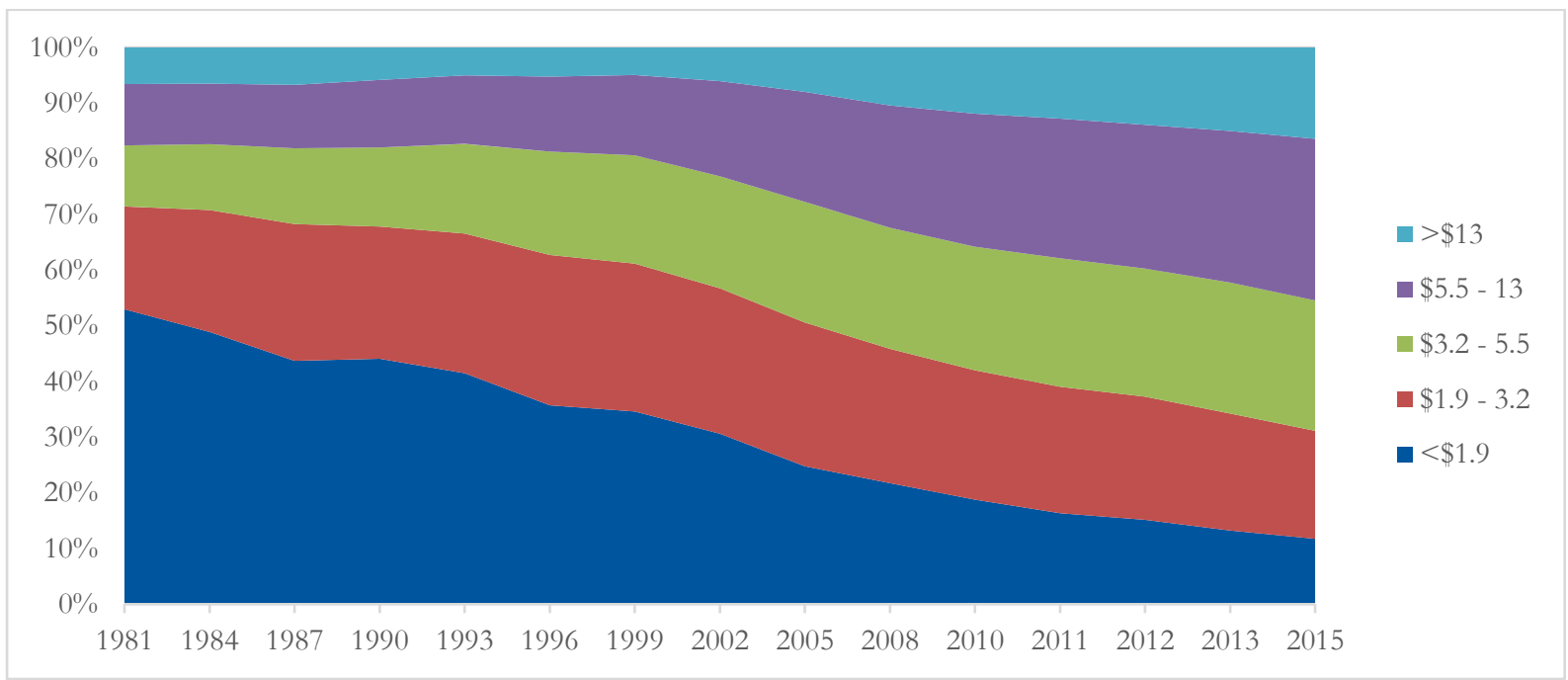

Notes: $\$ 3.20$ and $\$ 5.50$ are the World Bank higher poverty lines; the $\$ 13-$ per-day poverty line is derived from the methodology of López-Calva and Ortiz-Juarez (2014), updated to 2011 PPP\$.

Source: authors' estimates based on World Bank (2019a).

\section{Proposal for a universal development commitment}

\subsection{The context of the Sustainable Development Goals}

The shifts outlined above have played a role in shaping a new context for development and for the discussion about the successor to the Millennium Development Goals (MDGs). In September 2015, the UN agreed Transforming our World: The 2030 Agenda for Sustainable Development. This document included a set of 17 SDGs for 2030 underpinned by 169 targets and a commitment to 'leave no one behind'. One key difference between the MDGs and the SDGs is that the latter are global goals, applicable to all countries, not just the countries of the Global South. Another difference is the higher level of ambition for the SDGs in comparison with the MDGs, especially in that the SDGs contain a number of 'zero targets' - to eliminate extreme poverty, for example. Hence, it is hardly surprising that there is a good deal of contention over how the SDGs will be financed, the continued appropriateness of the 0.7 per cent target, and, more broadly, the existing governance of the global development finance architecture.

In terms of SDG financing, three points are pertinent. First, many countries need fewer concessional external resources to counter extreme poverty. But second, most countries require more concessional external resources if they are to have any chance of meeting the more ambitious SDG targets, as well as ending poverty above the $\$ 1.90$ per day mark. The SDG targets cover many more areas (such as climate change, conservation, inequality, technology, infrastructure, etc.), and even the social sectors that were the focus in the MDG era have targets that are far more ambitious. There has also been increasing recognition of the importance of financing 'global public goods', which by definition require international collaboration and co-operation. Climate change, environmental degradation, and pandemic diseases are some of the most obvious examples of cross-border threats to development that can only be addressed as a global community. Green infrastructure may be one of the most expensive up-front costs as the world seeks to save itself from climate chaos. So, the need for funding for globally agreed objectives is rising, rather than declining, in the SDG era. And third, the governance structures for international co-operation, 
including aid, need to be more democratic and reflective of a new, and still emerging, geopolitical order. That is, all countries require voice and representation. Many of the multilateral organizations-notably the UN, the Bretton Woods institutions, and the OECD-were established in the decades following the Second World War, when the levers of global power were controlled by a handful of powerful countries.

Further, the rules and guidelines around what constitutes 'aid' and what distinguishes it from more commercial types of finance are still co-ordinated by the OECD-DAC. Some of the emerging economies that are now aid donors — such as South Korea — seem broadly content to fit in with those rules and guidelines. However, the majority of new providers do not necessarily believe that they should have to follow DAC rules, having had no role in drawing them up, viewing them as North-centric, and preferring to develop their own practices and standards. Further still, many emerging economies do not wish to use the word 'aid', wanting to be perceived not as 'donors' but rather as 'partners' providing resources in solidarity with other countries in the Global South (even if complex power relations still exist between these countries: see discussion in Gulrajani and Swiss 2017, 2019). So, in a world of fewer very poor countries and higher ambitions, as well as a more economically and politically influential South with a growing sense that traditional governance structures need renewal, what should be the new direction for development financing?

\subsection{A universal development commitment}

Our proposal is a universal development commitment from all countries-rich and poor. This should not distract from the historic responsibility of wealthier countries to contribute vastly more to meet their 0.7 per cent ODA/GNI target where they are not already doing so. This is the case especially because 0.7 per cent is a symbolic statement about the historical obligations of the North and (in some cases) is perceived as a form of colonial reparations.

Three major questions emerge on the back of this proposal. What is the money for? What is the 'right' contribution for each country? And what new 'bargain' or deal would encourage MICs and the poorest countries to contribute and the OECD countries to meet their commitments?

First, what is the money for? A new universal development commitment would inevitably have the SDGs as its core focus, given that heads of state have signed up to the SDGs. As we noted earlier, more money is not the only factor relevant to achieving the agenda outlined in the SDGs. Yet if we consider the costs of meeting the zero targets set by the SDGs alone, the challenge of raising funds becomes painstakingly apparent, even if many of these costs are moving targets and are thus very difficult to estimate with real precision (see Table 2). Although the zero targets comprise just some of the SDGs, a few selected targets quickly add up to over US $\$ 300$ billion per year. In contrast, annual ODA is estimated at half that level currently. Clearly, there are other sources of funds to reach these targets-most importantly national taxation-but these figures are indicative of the challenge ahead, to which development co-operation must contribute.

Second, what is the 'right' contribution for each country? While there are undoubtedly challenges for the South in accepting the OECD definition of ODA, it is also recognized that a common conceptual and measurement framework is needed for quantifying South-South co-operation (SSC), ${ }^{4}$ if only to understand the contribution that southern countries are making to the SDGs that

4 South-South co-operation refers to financial, non-financial, and in-kind assistance provided between one developing country and another, and designates a collaborative framework that unites all countries of the South. 
they have committed to achieving (Besharati and MacFeely 2019)..$^{5}$ Given that there is growing interest in quantifying and defining the parameters of SSC, there may be an opportunity for generating North-South consensus on the elements of a shared numeric target. But even assuming that such a consensus could be reached, one might still ask whether a de facto flat tax is the right answer across countries. Should it be as a proportion of government spending rather than GNI, given the variations in public spending between countries? If all countries paid 0.7 per cent of GNI, this would raise almost US $\$ 600$ billion per year in total, or quadruple the current estimates of ODA volume (see Table 3). If HICs reached 0.7 per cent, this alone would add more than $\$ 200$ billion of new resources and amount to over $\$ 375$ billion per year from HICs, or 63 per cent of the total that could be raised. MICs could add $\$ 200$ billion of new resources. These figures would be gross.

Table 2: Indicative cost estimates of selected SDG zero targets

\begin{tabular}{|c|c|c|}
\hline SDG & Zero target & $\begin{array}{l}\text { Estimated cost of } \\
\text { meeting target (US } \$ \text {, } \\
\text { current dollars) }\end{array}$ \\
\hline 1 & By 2030 , eradicate extreme poverty & $\$ 75$ bn/year \\
\hline 2 & By 2030 , end hunger and malnutrition & $\$ 70$ bn/year \\
\hline 3 & $\begin{array}{l}\text { By } 2030 \text {, end preventable deaths of newborns and children under five years of } \\
\text { age }\end{array}$ & $\$ 10$ bn/year \\
\hline 4 & $\begin{array}{l}\text { By } 2030 \text {, ensure that all girls and boys complete primary and secondary } \\
\text { education }\end{array}$ & $\$ 17$ bn/year \\
\hline 6 & $\begin{array}{l}\text { By } 2030 \text {, achieve universal and equitable access to safe and affordable } \\
\text { drinking water for all } \\
\text { By } 2030 \text {, achieve access to adequate and equitable sanitation for all }\end{array}$ & $\begin{array}{l}\$ 28 \text { bn/year + capital } \\
\text { costs of } \\
\$ 114 \text { bn/year }\end{array}$ \\
\hline Total & & $\$ 314$ bn/year \\
\hline
\end{tabular}

Notes: estimates should be treated as indicative, as they are based on different assumptions and difficult-toestimate costs.

Sources: authors' construction based on cost estimates drawn from review of Kenny and Snyder (2017). See also Schmidt-Traub (2015).

It would be progressive to have a scaled contribution. One option would be a sliding scale. An arbitrary example to illustrate this idea would be that HICs would keep their commitment to 0.7 per cent of GNI, UMICs would contribute 0.35 per cent of GNI, lower-middle-income countries (LMICs) would contribute 0.2 per cent of GNI, and LICs would contribute just 0.1 per cent of their GNI to a universal development commitment. In this scenario, the total volume would be almost $\$ 500$ billion per year (see Table 3 ).

As noted, if all HICs reached 0.7 per cent, this would add more than $\$ 200$ billion of new resources, or approximately $\$ 375$ billion per year in total from HICs. This would be 80 per cent of the total raised in this scenario. UMICs would contribute approximately $\$ 85$ billion and LMICs and LICs respectively $\$ 13$ billion and $\$ 0.5$ billion. $^{6}$

Table 3: What if every country made a universal development commitment? Estimates by country income groupings

\begin{tabular}{|c|c|c|c|}
\hline $\begin{array}{l}\text { Country classification } \\
\text { (World Bank FY2020) }\end{array}$ & $\begin{array}{r}\text { Contribution as } \% \\
\text { of GNI }\end{array}$ & US\$ m & $\begin{array}{r}\text { Contribution as } \\
\% \text { of total }\end{array}$ \\
\hline
\end{tabular}

5 There is at least one effort, by the Center for Global Development (CGD), to develop a common metric for assessing the development finance contributions of all G20 members as a measure of their Commitment to Development Index.

${ }^{6}$ One potential issue is that this creates costs when countries move into a new World Bank income category. On one view, the answer would be to move from graduation to a gradated framework, i.e. for the first \$X of GNI per capita, the contribution rate should be $\mathrm{A} \%$, and then for the next $\$ Y$ of GNI per capita, the marginal rate should be $\mathrm{B} \%$. 


\begin{tabular}{lrrr}
\hline Low-income (28 countries) & 0.7 & $3,151.8$ & 0.5 \\
Lower-middle-income (47 countries) & 0.7 & $46,733.8$ & 7.9 \\
Upper-middle-income (59 countries) & 0.7 & $168,118.8$ & 28.3 \\
High-income (63 countries) & 0.7 & $376,660.9$ & 63.3 \\
World (197 countries) & & $594,665.3$ & 100.0 \\
& & & \\
Low-income (28 countries) & 0.1 & 450.3 & 0.1 \\
Lower-middle-income (47 countries) & 0.2 & $13,352.5$ & 2.8 \\
Upper-middle-income (59 countries) & 0.35 & $84,059.4$ & 17.7 \\
High-income (63 countries) & 0.7 & $376,660.9$ & 79.4 \\
World (197 countries) & - & $474,523.1$ & $100.0 \%$ \\
\hline
\end{tabular}

Note: GNI (current US\$) in 2018 for 185 countries. In 12 countries, the latest available GNI figures are as follows: Aruba, Bahamas, Barbados, Curacao, Iceland, and Iran (2017); Isle of Man, Liechtenstein, and South Sudan (2016); Cuba and Faroe Islands (2015); and Venezuela (2014).

Source: authors' estimates based on World Bank (2019b).

As noted, if all HICs reached 0.7 per cent, this would add more than $\$ 200$ billion of new resources, or approximately $\$ 375$ billion per year in total from HICs. This would be 80 per cent of the total raised in this scenario. UMICs would contribute approximately $\$ 85$ billion and LMICs and LICs respectively $\$ 13$ billion and $\$ 0.5$ billion. $^{7}$

What would these contributions 'buy'? The additional resources could in principle at least cover the end of $\$ 1.90$ poverty for approximately 750 million people (estimated cost of $\$ 75 \mathrm{bn} /$ year); the end of hunger and malnutrition for an estimated 1.5 billion people (estimated $\$ 70 \mathrm{bn} /$ year); the end of preventable child mortality (estimated $\$ 10 \mathrm{bn} /$ year); primary and secondary schooling for all girls and boys (estimated $\$ 17 \mathrm{bn} /$ year); and access to safe and affordable drinking water and adequate sanitation for over 1 billion people who lack access to safe water and over 2 billion people who lack adequate sanitation (estimated $\$ 142 \mathrm{bn} /$ year). ${ }^{8}$ And this would still leave $\$ 200$ billion of the $\$ 500$ billion in this scaled contribution scenario to support other SDGs. As with all concessional development finance, it would be important to ensure that delivery mechanisms maximized the chances of achieving the global goals in the most efficient and effective manner, and with the broad support of those citizens expected to benefit from this expenditure.

Finally, why might countries sign up to contributing to a universal development commitment? What would they get out of it? And what 'new bargain', in terms of the provision of new resources and the implementation of a new global governance structure, might persuade countries of the Global South to sign up to contributing to a new universal fund?

First, it should lead to more resources for developing countries overall. Using the European Union $(\mathrm{EU})$ as an analogy, the poorer countries of the EU pay into the EU budget as do the richer countries, but they receive far more back from EU funds. Hence, there is effectively a redistribution of money from richer to poorer EU members (see Glennie and Hurley 2014). At the national level as well, richer regions of countries tend to see their tax contributions redistributed to poorer regions, but those poorer regions still contribute to the overall tax revenue. In joining a consensus around a differential global target, developing countries would help to

\footnotetext{
${ }^{7}$ One potential issue is that this creates costs when countries move into a new World Bank income category. On one view, the answer would be to move from graduation to a gradated framework, i.e. for the first \$X of GNI per capita, the contribution rate should be $\mathrm{A} \%$, and then for the next $\$ Y$ of GNI per capita, the marginal rate should be $\mathrm{B} \%$.

8 The multidimensional poverty data in this paragraph are taken from Robles Aguilar and Sumner (2020). Estimates for ending poverty are drawn from Table 2.
} 
generate a much larger international fund from which developing countries would be the beneficiaries. Another example is the Pacific Islands' existential threat from rising sea levels resulting from global warming: a rational response is for them to put some modest funding into the International Climate Facility, if this helps to ratchet up much larger contributions from betteroff members of the international community.

Second, and equally important, contributing would ensure that poorer countries have a seat at the table, sometimes metaphorically/symbolically (i.e. contributor countries have a moral right to be heard) and sometimes physically, as contributor countries would sit on the boards deciding on priorities and policies. Poorer countries' engagement as contributors of international public finance, rather than just as recipients, would fundamentally rewrite the rules of engagement in line with the universal vision of the SDGs. The world would no longer be split into donors and recipients, insofar as all countries would be contributing to global progress. Furthermore, this would have implications for global governance and decision-making. Poorer countries might agree to some kind of universal commitment in exchange for the rebalancing of multilateral organizations to reflect contemporary geopolitical power and influence. In short, this is essentially a 'rebalancing' agenda, not a proposal for all to shoulder the commitment without sharing power (particularly through global institutions).

There are various other questions - notably, the demarcation between what counts and what does not in terms of policies for domestic populations versus policies that go beyond national borders. For example, MICs are among the biggest funders of poverty relief to the extreme poor already (within their own borders). Might this be included in commitments? Why should developing countries give to other countries when they still have extreme poverty domestically? Should a universal commitment include estimates of the monetary impact of non-financial policy actions in, for example, better trade policy? In short, we might distinguish what governments do to relieve poverty within their own countries (e.g. the provision of basic health coverage) from what governments might do within their own countries but where the primary objective of the intervention is not only domestic but is also to support global wellbeing (e.g. protection of rainforests). These are of course not watertight categories: addressing health issues within a particular country would help to prevent spread of infectious diseases across borders, just as stopping the destruction of the rainforest would bring benefits within a country as well as to the wider international community. Is it plausible that the first of these would not count towards a universal development commitment (because it is a government responsibility) but the second should (because it is taking on an international responsibility)? These and various other questions would need discussion.

\section{Conclusion}

The starting point of this paper was the 50 -year birthday of the 0.7 per cent commitment and current discussions around the financing of the SDGs. Most HICs have for the past half-century accepted, in principle if not in practice, the commitment of contributing 0.7 per cent of their GNI each year towards the provision of concessional resources to support the development of poorer countries. Yet this paper has argued that all countries should contribute to a new universal development commitment, without removing the responsibility of the North to redistribute funds globally to poorer countries.

This is a provocative proposal. What might the response be, and what challenges might it face? First, some of the OECD-DAC countries have still not met the 0.7 per cent target. How can other 
countries contemplate contributing significantly while that remains the case? This critique is well articulated by, for instance, Besharati (2013: 40):

$[1] \mathrm{t}$ would be inappropriate for Southern countries to be pressured into quantitative targets for external assistance when they still have so much poverty and socio-economic challenges at home to address ... it would be out of place for traditional donors to expect a similar effort from new partners, when only a few European countries (such as the Nordic countries, Luxembourg, the Netherlands and the United Kingdom) have managed to fulfil the $0.7 \%$ target in decades of development cooperation.

However, many development co-operation providers are more comfortable with 'common but differentiated responsibilities' (CBDR), as they feel that the better-off economies should be doing more, and this might be perfectly compatible with a universal development commitment. At the same time, care must be taken to avoid CBDR becoming cover for the Global South to retreat from global responsibilities (Bracho et al. 2015).

Second, many of the additional resources that might be generated should be expected to accrue to organizations financing global public goods, such as fighting climate change-though there is currently an undoubted shift away from multilateralism that is at odds with this notion. So, is this idea just not plausible in our contemporary and polarized world? Third, what is the 'right' amount for developing countries to contribute, given that ODA is currently viewed as a rich-country commitment to the Global South? Fourth, and perhaps most importantly for southern governments, how would global governance structures be rebalanced to respond to this new approach to international development co-operation?

In the end, making progress on a universal development commitment of this kind, as with so much else, will depend on politics and what numbers and percentages prove acceptable to all parties involved. Progress on the SDGs is not only about finance but it will certainly require substantial additional resources, and a universal and scaled commitment by governments is one way in which global solidarity can be expressed.

\section{References}

Alonso, J.A., J. Glennie, and A. Sumner (2014). 'Recipients and Contributors: Middle Income Countries and the Future of Development Cooperation'. DESA Working Paper 135. New York: UN Department of Economic and Social Affairs (UNDESA).

Besharati, N.A. (2013). 'Common Goals and Differential Commitments: The Role of Emerging Economies in Global Development'. Discussion Paper 26/2013. Bonn: Deutsches Institut für Entwicklungspolitik (German Development Institute).

Besharati, N., and S. MacFeely (2019). 'Defining and Quantifying South-South Cooperation'. UNCTAD Research Paper 30. Geneva: UN Conference on Trade and Development (UNCTAD).

Bracho, G. (2015). 'In Search of a Narrative for Southern Providers: The Challenge of the Emerging Economies to the Development Cooperation Agenda'. Discussion Paper 1/2015. Bonn: Deutsches Institut für Entwicklungspolitik. 
Bracho, G., C. Heinesche, and S. Weinlich (2015) 'Addis Ababa: Trying to Square the Circle, orHow to Share Responsibilities in an Unequal World'. The Current Column. Bonn: Deutsches Institut für Entwicklungspolitik.

Clemens, M.A., and T.J. Moss (2005). 'Ghost of 0.7\%: Origins and Relevance of the International Aid Target'. Working Paper 68. Washington, DC: Center for Global Development.

Edward, P., and A. Sumner (2015) 'New Estimates of Global Poverty and Inequality: How Much Difference Do Price Data Really Make?’ Working Paper 403. Washington, DC: Center for Global Development.

Fouré, J., A. Bénassy-Quéré, and L. Fontagne (2012). 'The Great Shift: Macroeconomic Projections for the World Economy at the 2050 Horizon'. CEPII Working Paper 2012-03. Paris: Centre d'Études Prospectives et d'Informations Internationale.

Glennie, J., and G. Hurley (2014). 'Europe's Aid Experience Shows the Value of Supporting Middle-Income Countries'. The Guardian, 7 May. Available at: www.theguardian.com/globaldevelopment/poverty-matters/2014/may/07/europe-aid-eu-middle-income-countries (accessed 1 October 2019).

Gulrajani, N., and L. Swiss (2018). 'Donor Proliferation to What Ends? New Donor Countries and the Search for Legitimacy'. Canadian Journal of Development Studies/Revue Canadienne d'études Du Développement, online: 348-68. doi: https:/ / doi.org/10.1080/02255189.2019.1543652.

Gulrajani, N., and L. Swiss (2019). 'Donorship in a State of Flux'. In I. Olivia and A. Perez (eds.), Aid Power and Politics. London: Routledge.

IMF (2019). 'World Economic Outlook Databases'. Washington, DC: IMF. Available at: https://www.imf.org/en/Publications/SPROLLs/world-economic-outlookdatabases\#sort=\%40imfdate\%20descending (accessed 1 September 2019).

Kenny, C., and M. Snyder (2017). 'Meeting the Sustainable Development Goal Zero Targets: What Could We Do?’ Working Paper 472. Washington, DC: Center for Global Development.

Leigh, C., and J. Glennie (2013). 'Aid Targets Are Aspirational-So Let's Apply Them to Every Country'. The Guardian, 28 March. Available at: www.theguardian.com/globaldevelopment/poverty-matters/2013/mar/28/aid-targets-aspirational-apply-everycountry\#start-of-comments (accessed 1 October 2019).

López-Calva, L., and E. Ortiz-Juarez (2014). 'A Vulnerability Approach to the Definition of the Middle Class'. Journal of Economic Inequality, 12: 23-47.

Luijkx, W., and J. Benn (2017). 'Emerging Providers' International Co-operation for Development'. OECD Development Co-operation Working Paper 33. Paris: OECD.

Maxwell, S. (2006). 'What's Next in International Development? Perspectives from the $20 \%$ Club and the 0.2\% Club'. Working Paper 270. London: Overseas Development Institute.

OECD (2018). 'Development Co-operation Report 2018: Joining Forces to Leave No One Behind'. Paris: OECD.

Robles Aguilar, G., and A. Sumner (2020). 'Who Are the World's Poor? A New Profile of Global Multidimensional Poverty'. World Development, 126: 1-15.

Schmidt-Traub, G. (2015). 'Investment Needs to Achieve the Sustainable Development Goals: Understanding the Billions and Trillions'. SDSN Working Paper. Paris and New York: Sustainable Development Solutions Network. 
Schmidt-Traub, G., and J.D. Sachs (2015). 'Financing for Sustainable Development: Implementing the SDGs through Effective Investment Strategies and Partnerships'. SDSN Working Paper. Paris and New York: Sustainable Development Solutions Network.

UN (2015), Transforming our World: The 2030 Agenda for Sustainable Development. New York: United Nations.

Wickstead, M.A. (2015). Aid and Development: A Brief Introduction. Oxford: Oxford University Press.

World Bank (2019a). 'PovcalNet'. Washington, DC: World Bank. Available at: http://iresearch.worldbank.org/PovcalNet/povOnDemand.aspx (accessed 1 October 2019).

World Bank (2019b). 'World Development Indicators'. Washington, DC: World Bank. Available at: https://datacatalog.worldbank.org/dataset/world-development-indicators (accessed 1 October 2019). 